\title{
Development of a Competency-Based Management Model in the Production Unit of Sekolah Menengah Kejuruan Negeri 1 Panyabungan
}

\author{
Ahmad Imadi Batubara ${ }^{1 *}$, Rosmala Dewi², Ibnu Hajar ${ }^{2}$ \\ \{*imadiahmad1977@gmail.com\} \\ Post Graduate State University of Medan, Indonesia ${ }^{1}$, Lecturer State University of Medan, Indonesia ${ }^{2}$
}

\begin{abstract}
This study aims to find a competency-based management model of Management Field Management in the Production Unit of Sekolah Menengah Kejuruan (SMK) Negeri 1 Panyabungan; knowing the appropriate Competency Based Management Product Operational Standards (SOP) applied in the Production Unit of SMK Negeri 1 Panyabungan; find out the results (output) of the application of the Expertise Competency Based Management Model in the Production Unit of SMK Negeri 1 Panyabungan. The number of research samples was 90 students with purposive sampling technique. Data is collected by observation, inventory, questionnaire, and documentation. Hypothesis testing is done with i-t test and the calculation process is carried out with the help of SPPS. From the two trials, the results of the average production unit management were found; the first trial was $93.12 \%$, the second trial was 96\%. And the results of the study show that: First, the Management Competency-Based Management Model of Business Management Skills is feasible to be applied in the Production Unit of SMK Negeri 1 Panyabungan. Second, Establishing Operational Standards (SOP) for Management Based on Competencies in Business Management Field Management is precisely carried out in the Production Unit of SMK Negeri 1 Panyabungan. Third, Producing a Competency-Based Management Model in the Management Business Field of the Production Unit of SMK Negeri 1 Panyabungan consists of two components, namely the Product Unit as the source of production and the Production Unit as a source of funding concludes that $96.5 \%$ is very good if implemented..
\end{abstract}

Keywords: Development of Management Models, Expertise Competencies, Production Units, Vocational Schools.

\section{Introduction}

Education is a basic need for all beings who have the means of thinking, namely reason. Almost everyone defines that education is sending their children to a school that provides knowledge to their children. In short, for the general public education is only obtained in schools. Therefore, improving the quality of education needs to be done to train the younger generation to develop the progress of the nation that will be able to answer global challenges in facing its future. One of the educational institutions that are heavily related to labor problems is Vocational High Schools (the so called SMK). Vocational education is an educational path that aims to train students to become trained, competitive and productive workforce in accordance with their respective fields. Unfortunately, this cannot be true. 
Vocational education is part of an education system that prepares a person to be better able to work in one group of work or one field of work than in other occupational fields. To produce graduates of the vocational high school must be productive people. According to the Law No. 20 of 2003 concerning the National Education System: Vocational education is an education that prepares students to be able to work in certain fields. However, there are constraints that must be faced by vocational education, namely: (1) relavance and quality of vocational secondary education is still low, (2) access to vocational secondary education services is inadequate, and (3) education management is still not efficient. To deal with these obstacles, one of the methods taken is to make improvements in the teaching-learning process in vocational schools.

From the observations carried out by researchers starting in January 2017, information was obtained that SMK Negeri 1 Panyabungan is a Business Management Vocational School. Initially this school took care of only the business and management fields of accounting expertise, office administration and marketing competence. Along with the progress of the times and the needs of the world of work in 2006, the Computer and Network Engineering $(T K J)$ expertise program was opened in the field of Information Technology and then developed again starting in 2016, the Multi Media and Banking expertise program was opened again. This school is one of the vocational schools that have implemented Production Unit $(U P)$. Management of UP in SMK Negeri 1 Panyabungan is carried out to enhance the potential of each study program in the form of services and goods consisting of the business fields of Stores, Mini Banks, Student Canteens, Typing Services, Photo Copy, Computer Screen Printing, Animation Design, Photographers, Computer, Warnet and Internet Network installation services.

Activities carried out at the UP marketing branch are management of student canteens and shops selling office equipment, electronic goods, basic needs of students, basic needs of the community and promotion of student services to the general public and other expertise programs. Branch UP accounting and banking activities have a mini bank services unit. Financial services managed are credit and debit services to customers for senior high school (SMA / SMK / MA) students in Mandailing Natal District. Where the mini bank works with 3 Commercial Banks, namely: North Sumatra Bank, Bank Rakyat Indonesia, and Bank Mandiri in the Panyabungan Branch. Activities at the Branch UP Office Administration are engaged in services in the type and photo copy in 3 (three) unit locations in Panyabungan. The location is placed in a strategic area, so that the services offered are very much visited by customers, both students, employees up to the general public. Branch UP TKJ and multimedia activities are computer service services, animation designers, computer screen printing and internet networks have 3 (three) units as well.

Many experts say about the understanding of the model according to the Indonesian Dictionary, model is defined as a pattern (example, reference, variety) of something that will be created or produced (Pusat Bahasa, 2013: 75) Meanwhile, according to Martubi "The model is the abstraction of reality by focusing on several characteristics of real life [2]. Based on the opinions above it can be concluded that the model is a form of pattern that is emulated, either in physical form of a work or a picture (abtraction) of reality. Hasibuan said that: "Management is the science and art of managing the process of utilizing human resources and other resources effectively and efficiently to achieve a specific goal [3]. While Griffin suggested that management is the process of working together between individuals and groups and other resources in achieving organizational goals as activities of management [4]. From several definitions or understanding of management above, it can be summed up that management is: (a) the existence of cooperation between elements within an organization; (b) 
the existence of an effort to utilize the elements of the organization; (c) the existence of clear objectives to be achieved by the organization; (d) arrangements to achieve organizational goals.

According to Mulyasa the competence of expertise is a combination of knowledge, skills and attitudes that reflect in the habit of thinking and acting [5]. Further According to Boyatzis argues that the competence of expertise is the capacity that exists in someone who can make the person able to fulfill what is indicated by work in an organization capable of achieving the expected results [6]. From the definition of the statement above it can be concluded that the competence of expertise is defined as a set of mastery of skills, values and attitudes that must be possessed and mastered by students according to standards set by the government sourced from education, training and experience so that they can work professionally. From the description of the competency management management model development above, a conclusion can be drawn that the purpose of the competency-based management model development expertise in this study is an effort to utilize existing resources through planning, organizing, mobilizing and controlling to achieve the knowledge, skills and attitudes possessed students according to the graduates' competency standards (SKL) SMK.

Vocational secondary education is the only one from the education system in schools that is specifically prepared to produce mid-level skilled labor to fill the needs of business, industry and development. In order to achieve the objectives of the defined production unit, schools in running this business unit must always carry out good management. Therefore, in implementing the production unit program, the school makes a management model, which is a business that produces goods or services, optimally utilizing all forms of capital in schools and management which are supported by a chain or business network that requires each other or mutually beneficial. In addition, businesses in the form of production units need to be supported by the management system such as: marketing, promotion, research and development, quality control, and others. Based on the link and match concept that has been mentioned that one of the realization is the production unit management policy at the school. The production unit can be said to be a miniature of a company that has a lot to do with everything related to the company, namely: business status, goals, objectives, scope and management in the business. Furthermore, business fields can be classified into production and services. The service sector is a business that can be directly enjoyed by consumers, while businesses in the field of production generally cannot be directly enjoyed by consumers.

\section{Methodology}

The study was conducted at Panyabungan Vocational School 1, the so-called SMK Negeri Panyabungan 1, in Mandailing Natal District, North Sumatra Province. Limited trial subjects involved 35 respondents / sample students. The trial subject was expanded to work effectiveness analysis of the management model involving 60 students in the Business Management Competency-Based Production Unit Expert group participants and 60 students in the control group of the conventional Production Unit implementing participants including 5\% experimental experiment reserve. Determination of the experimental group with random selection. The sample of the experimental and control groups represented the student population in each skill program at SMK 1 Panyabungan which included 4 Expertise Programs (Accounting Skills Program, Office Administration, Marketing, and Banking). 
The method used in this study is the research and development model or Research and Development (Borg \& Gall, 1983; 772). As for what was developed in this study is the Management Competency-Based Management model in the Production Unit. The development model that is carried out is by testing the model or product. Model or product trials are a very important part of development research, which is carried out after the product design is complete. The trial of the model or product aims to find out whether the product made is suitable for use or not. The trial of the model or product also looks at the extent to which the product made can achieve the goals and objectives. The trial was conducted 3 times: (1) two limited tests were carried out on small groups; and (2) field tests (testing fields).

Trial, the quality of the model or product developed is truly valid construct empirically. The steps in carrying out the analysis taken in the development research (research and development) include: (1) collecting data through discussion or focus group discussions (FGD), (2) designing the research, (3) developing the model, (4) testing limited phase I (5) revising the trial hasill model (6) strengthening the model is done by limited trial II to different schools, (7) refinement of the model, (8) strengthening the model with field testing in rayon schools, (9) refinement model, and (10) dissemination and implementation. The development of the model in this study is referred to as the Competence-Based Skill Management Model with the Organizing System in FGD (Focus Group Discussion) activities and experiments.

Research and development in this case is used as a procedure to develop a Management Competency-based management model in the Production Unit at SMK Negeri 1 Panyabungan in various skill programs. Based on the research procedure, it is expected to produce a product in the form of Management Competency Based Business Management Skills model in the Production Unit of SMK 1 Panyabungan that meets the principles of link and match which is a necessity for the growth of independent entrepreneurial spirit based on the students' competency with educational institutions with various transitions from workplace school.

Thus the development model in this study includes preliminary investigation activities, determine the plan and define direction, design development, demonstrate, design, evaluate and revise trials (test, evaluation and revision), developing, and presenting development results. In accordance with existing instruments, data collection techniques used in this study are questionnaire techniques, interviews, and documentation. In this case the research instrument is distributed directly to students who are members of the Production Unit. The experimental group and the control group as respondents were filled out. In order for the instrument to be filled with full concentration, there is a sufficient / different time lag between the distribution of test instruments and questionnaires to respondents or samples.

The data analysis process begins by gathering all the things obtained by the author from several sources: students who are members of the Production Unit, the consents are directly related to the activities of the Production Unit, then summarized, selected, categorized and interpreted according to the focus of the discussion in the study with the Focus Group Discussion model (FGD) together with the manager of the Head of the Production Unit of SMK Negeri 1 Panyabungan and combined with SWOT analysis techniques (Strengths, Weaknesses, Opportunities and Threats) for Human Resources related to the Production Unit. Data analysis techniques include data analysis of model development and analysis of experimental data. Data analysis of model development with this construct is done by confirmatory factor analysis or Confirmatory Factor Analysis (CFA). Validity test aims to determine the ability of indicators in measuring variabellaten. 


\section{Result and Discussion}

Since the merger of SMK Negeri 1 was established in 1990 having its address at Jalan Sukaramai Aek Galoga Panyabungan, located at 61 SL and 120 NL. Until now, SMK Negeri 1 Panyabungan apart from having the facilities and infrastructure as the supporting capacity of scientific development that is needed also has a reliable teaching staff, both in terms of quality and quantity, the development of the Production Unit $(U P)$ of each expertise program is a priority plan this school. Joint Venture 1 State Vocational School in the 2017/2018 school year has 58 educators. In terms of facilities, SMK Negeri 1 Panyabungan has a laboratory, library, small mosque, guesthouse, shared learning resource center (PSBB), art facilities and sports, and also has free hotspot facilities for internet use.

The key to the success of SMK Negeri 1 Panyabungan in creating skilled and competent medium power, lies in the ability of Human Resources (HR), especially teachers. To obtain quality human resources, the SMK Negeri 1 Panyabungan training and development for teaching staff to be more competent in the field of competence they have, and the knowledge is transformed to students through real work in the development of school production units. The Production Unit $(U P)$ is carried out with the goal of students gradually and will be accustomed to being skilled to develop small businesses which are expected to provide experience in entrepreneurship and manage it properly and appropriately, so that after completing their education they will be able to create their own jobs or be able to compete with the people around him.

The dimensions of activities in this study are the management of the Production Unit which consists of the Production Unit as a learning resource and the Production Unit as a source of funding. Production Unit activities as learning resources and Production Units as funding sources are seen from the POAC management function (Planning, Organizing, Actuating, and Controlling). In the planning stage the model is focused on (1) formulating the objectives of model building, in this case the management of the SMK Production Unit Business and Management Expertise Study Program; (2) determine the target user of the model, namely the leader and manager of the Production Unit who can utilize in terms of the management of the Production Unit management; (3) and specify the model components, namely the model components that make it easier for users to implement the model. In this case the management component of the Production Unit contains the Production Unit as a learning resource and the Production Unit as a source of funding, the clarity of the component model structure, the clarity of the relationship between the components of the school funding source development model, the readability of the model and the feasibility of the model.

In the model development stage the following things are done: (1) the first stage model validation; (2) model revision; (3) second stage model validation; and (4) revision of the operational model. Model testing was carried out in two stages: the expert judgment stage and the model effectiveness test stage. The expert judgment stage is to ask a number of people who have expertise in the development of management models of the SMK Production Unit in the Business Management Field of Management to provide an assessment of the model that has been developed. The steps taken are as follows: (1) determine the management development model of the SMK Production Unit Business and Management Expertise Study Program the results of previous development; (2) establishing panelist members based on expertise; (3) preparing instrument items based on the model variables proposed; (4) sending questionnaires to instrument answers and correcting the model to be returned; (5) send back the repaired model for review; (6) the researcher invites panelists to clarify and discuss the answers and revised notes stated so that a consensus is reached; and (7) make a report. 
The trial of the effectiveness of the model is intended to test the level of effectiveness of the model in its use. The target of the trial was chosen based on respondents who had expertise in the field of application of the management model of the SMK Production Unit Business and Management Expertise Study Program. The trial of the effectiveness of the model used a questionnaire containing the opinions / perceptions of respondents on the effectiveness of the proposed model. Because this model has not been implemented for actual implementation, it is called internal effectiveness.

Production units and school services are a process of business activities carried out by schools / madrasas on an ongoing, academic and business basis by empowering school / madrasah citizens and the environment in the form of production / service business units that are managed professionally. Because production units and school services are a place of entrepreneurship in schools, they must be managed academically/ business and institutionalized in a business entity. The purpose of carrying out production activities and services in schools is:

a. production / service based training facilities for students,

b. grow and develop the entrepreneurial spirit of teachers and students,

c. help funding for maintenance, additional facilities and other educational operational costs,

d. increase the spirit of togetherness to increase productive activities and welfare for teachers and students,

e. develop an independent and confident attitude in the implementation of student practice activities,

f. Increasing creativity and innovation among students, teachers and school management, as well as building the ability of schools to establish synergic collaboration with local parties and the wider community.

As a learning resource for students and funding sources for education in schools, management of production units and school services is developed by developing principles; independence, accountability, transparency, partnership, participation, effective and efficient. Based on the explanation related to Production Unit management that occurred at SMK Negeri 1 Panyabungan, there were found some problems and weaknesses that often occur in the Production Unit management so that the results obtained from the implementation of Production Unit management were not optimal, the problems were: first, not all schools have building facilities which is sufficient to be used as a Production Unit. Second, Production Unit planning is still monotonous. Third, the organization that still overlaps. Fourth, the implementation of learning in the Production Unit does not run in several schools. Fifth, people outside of school still lack trust in the production / service results from the SMK Production Unit. Sixth, in SMK 1 Panyabungan, the results of the Production Unit are used to finance extracurricular activities. Seventh, supervision of the Production Unit at SMK Negeri 1 Panyabungan directly from the Inspectorate, so the school feels objected if the results of the Production Unit must be deposited in the State Treasury. Therefore, steps to bridge the problems that occur in the management of the existing SMK Production Units, it is necessary to develop a Production Unit management model. The results of the development of the SMK Production Unit management model are expected to be a solution to achieve the ideal goals of the Production Unit activities and are feasible to be applied in SMK.

The development of the SMK Production Unit management model is focused on two components supporting the management of the Production Unit, namely the Production Unit as a learning resource and the Production Unit as a source of funding. The contents of the 
components The production unit as a learning resource consists of four management aspects, namely: (1) planning consisting of a clear vision, mission, and objectives as the first step in the formation of a Production Unit; (2) organizing consists of guidelines for organizing organizations, organizational structures and job descriptions; (3) the implementation consists of the division of the teacher's duties, the division of tasks of the teaching staff, the syllabus$R P P$, and the rules of learning in the Production Unit; and (4) supervision consists of supervision of students, internal evaluation of the production unit, and evaluation of education educators.

The Production Unit as a funding source consists of four management aspects, namely: (1) planning consisting of: business environment analysis design, service product overview, competition analysis, price strategy, overview of competitive advantages of the SMK Production Unit, overview of market segmentation methods used, overview location, description of promotional plans, identification of management and personnel, unpredictable risks, and identification of raw material suppliers; (2) organizing is made the organizational structure and job descrip-tion; (3) implementation consisting of excellent ser-vice activities, production unit production time settings, production personnel arrangements, produc-tion layouts, production support equipment and mar-keting management; and (4) supervision which con-sists of supervision of costs, quality and time of pro-duction, personal supervision and submission of claims-sanctions.

\subsection{Management Model of the Production Unit}

Based on the explanation of the theory and concept of the Production Unit formulated a Production Unit management model consisting of components of the Production Unit as learning resources and as a source of funding. All components cannot be separated from one another. Through the production unit, students learn about how to plan, implement and supervise the course of the production unit, study customer tastes, plan products, product feasibility, financial administra-tion, marketing techniques, negotiating techniques, service to customers and others.

From various learning activities in the Production Unit can be obtained the skills, knowledge, and direct experience that is beneficial for the development of students. The real learning experience can increase various skills knowledge, among others, the ability to sell, communication techniques, producing skills, ana-lyzing business opportunities, designing products, planning business, calculating or taking risks, and so on. In addition, students learn about honesty, tenacity, independence, respect for time, respect for people, thorough, responsible and various other entrepreneu-rial traits.

The Production Unit as a source of funding is one way to maximize one of the potential possessed by the school. Through the Production Unit container, all student creativity and the results of the students' competence can have economic value that is useful to improve the welfare of all school residents.

\subsection{Product Test Results}

The trial of the effectiveness of the model is intended to test the level of effectiveness of the model in its use. The target of the trial was chosen based on respondents who had expertise in the field of application of the management model of the SMK Production Unit for Business and Management Expertise. The trial of the effectiveness of the model used a questionnaire containing the opinions / perceptions of respondents on the effectiveness of the proposed 
model. Because this model has not been implemented for actual implementation, it is called internal effectiveness.

The trial was conducted 2 (two) times involving 90 respondents consisting of 40 respondents in the limited trial I; 20 people majoring in Accounting, and 20 people majoring in Office Administration. Furthermore, the number of respondents was expanded to 50 respondents in the second limited trial; 25 people majoring in Marketing, and 25 people majoring in Banking.

First trial. In the limited trial I was intended to see the feasibility of implementing a Production Unit management model developed by researchers, by managers to be used in the implementation of Production Units for students majoring in Accounting and Office Administration. This trial was conducted to distribute questionnaires to 40 respondents consisting of 25 questions by focusing on 4 (four) main variables, namely; 1) planning, 2) organizing, 3) implementation, and 4) supervision. The results of the analysis of data collected from the trials can be reported in Table 1 .

Table 1. Limited trial results I in Accounting and Office

\begin{tabular}{|c|c|c|c|c|c|}
\hline \multirow{2}{*}{$\begin{array}{l}\text { The variables } \\
\text { examined were }\end{array}$} & \multicolumn{4}{|c|}{ Respondent Answer } & \multirow{2}{*}{ Total } \\
\hline & SL & SR & JR & $\mathrm{TP}$ & \\
\hline Planning Up & 36 & 4 & - & - & 40 \\
\hline Organizing Up & 35 & 5 & - & - & 40 \\
\hline $\begin{array}{l}\text { Implementation Of } \\
\text { Up }\end{array}$ & 38 & 2 & - & - & 40 \\
\hline Supervision Up & 40 & 0 & - & - & 40 \\
\hline Total & 149 & 11 & 0 & 0 & 160 \\
\hline Average (\%) & $93,12 \%$ & $6,88 \%$ & 0 & 0 & $100 \%$ \\
\hline
\end{tabular}

Source: Data processed by questionnaire

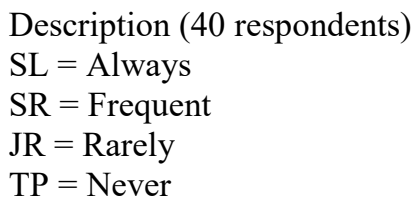

From the presentation Table 1 above shows that the Management Unit of the Business and Management Field of Business in Accounting and Office Expertise Competencies has a good level of efficiency. Where based on the results of the distribution of questionnaires collected shows; a) Planning; SL reaches $90 \%$, and the rest SR has a $10 \%$ achievement, b) Organizing; SL reaches $87.5 \%$, and the rest is SR at $12.5 \%$, c) Implementation; SL reaches $95 \%$, and the rest is SR at 5\%, and d) Supervision, all respondents answer Always (SL) so it reaches $100 \%$. Thus, the average achievement from the results of the first trial was $93.12 \%$.

Second Trial. In the limited trial II was intended to see the feasibility of the implementation of the Production Unit management model developed by researchers, by managers to be used in the implementation of the Production Unit for students majoring in Marketing and Finance. Also test the suitability of the model and test the instruments that have been made. This trial was conducted to distribute questionnaires to 50 respondents as in the previous Trial consisting of 25 questions by focusing on 4 (four) main variables, namely; 1 ) planning, 2) organizing, 3) implementation, and 4) supervision. The results of the analysis of data collected from the trials can be reported in Table 2 . 
Table 2. Results of limited trial II in the Department of Marketing and Banking

\begin{tabular}{|c|c|c|c|c|c|}
\hline \multirow{2}{*}{$\begin{array}{l}\text { The Variables } \\
\text { Examined Were }\end{array}$} & \multicolumn{4}{|c|}{ Respondent Answer } & \multirow{2}{*}{ Total } \\
\hline & SL & SR & JR & TP & \\
\hline Planning Up & 48 & 2 & - & - & 50 \\
\hline Organizing Up & 49 & 1 & - & - & 50 \\
\hline $\begin{array}{l}\text { Implementation } \\
\text { Of Up }\end{array}$ & 47 & 3 & - & - & 50 \\
\hline Supervision Up & 48 & 2 & - & - & 50 \\
\hline Total & 192 & 11 & 0 & 0 & 200 \\
\hline Average (\%) & $96,00 \%$ & $4,00 \%$ & 0 & 0 & $100 \%$ \\
\hline
\end{tabular}

$$
\begin{aligned}
& \text { Description (40 respondents) } \\
& \mathrm{SL}=\text { Always } \\
& \mathrm{SR}=\text { Frequent } \\
& \mathrm{JR}=\text { Rarely } \\
& \mathrm{TP}=\text { Never }
\end{aligned}
$$

From the table Table 2 above shows that the Management Unit of the Marketing and Banking Group's Business and Management Expertise Program management model has a good level of efficiency. Where based on the results of the distribution of questionnaires collected shows; a) Planning; SL reaches 96\%, and the rest SR has a 4\% achievement, b) Organizing; SL reaches $98 \%$, and the rest SR is $2 \%$, c) Implementation; SL reaches 94\%, and the rest SR is at $6 \%$, and d) Supervision, all respondents answer Always (SL) so that it reaches $96 \%$. Thus, the average achievement from the results of the first trial was $96.00 \%$.

\subsection{Final Product Study}

The development of competency-based competency management models in the SMK Production Unit Business and Management Skills is a Production Unit management model that can be carried out by SMK Negeri 1 Panyabungan so as to maximize the potential of students, teachers, and schools that can improve student competence and generate income generating. The development of competency-based management models in the Production Unit of SMK Negeri 1 Panyabungan Management Business Expertise Field has been tested qualitatively and the results show that this model is quite clear, practical and suitable for the Business Management expertise. The explanation and characteristics of skill competencybased Management Model Development in the Production Unit of SMK Negeri 1 Panyabungan Management Business Field can be seen in Figure 1.

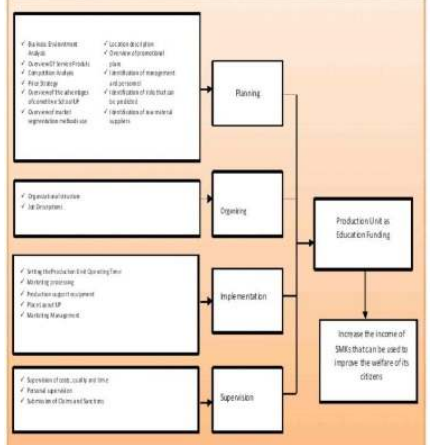

Fig. Final Model of Management of Production Units of SMK Production Unit Components as Learning Resources 


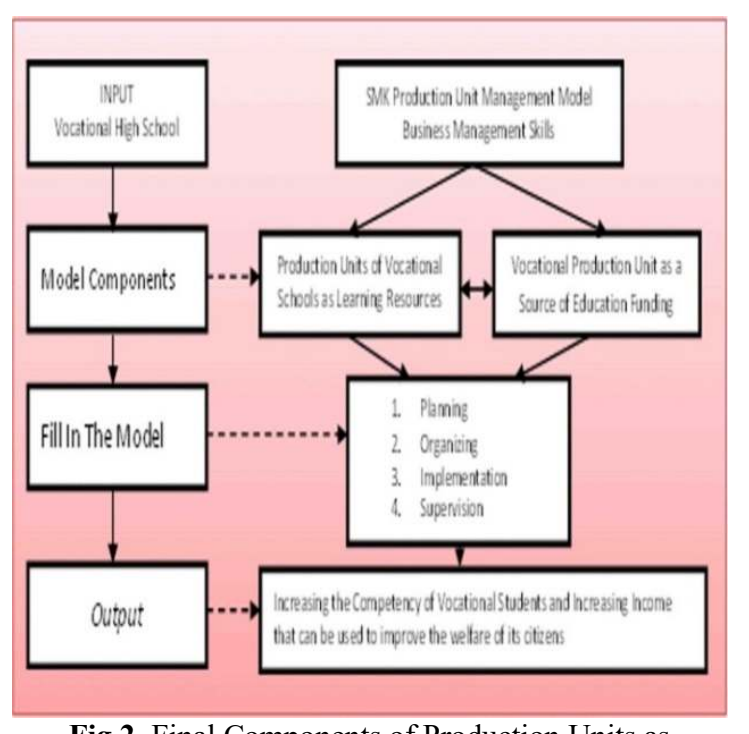

Fig.2. Final Components of Production Units as Learning Sources

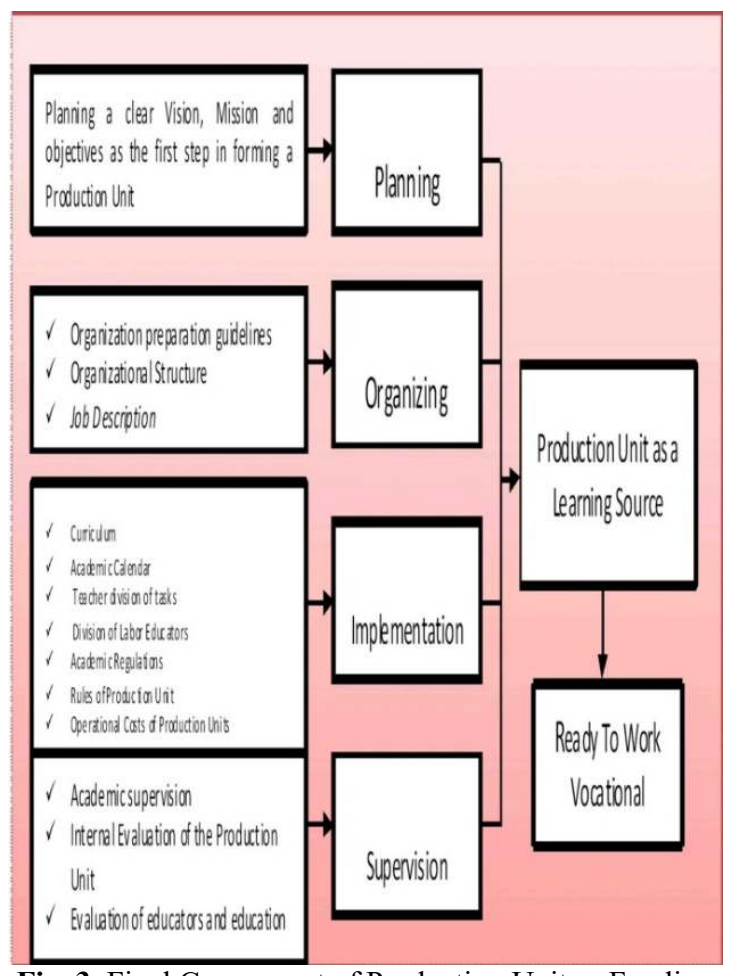

Fig. 3. Final Component of Production Unit as Funding Source.

\section{Conclusion}

Based on the research results that have been discussed, and from the results of trials I and II in the field it can be concluded the following results:

a. the Production Unit of Business and Mana-gement Competency Skills that need to be developed are: Office Administration, Accounting, Banking, and Marketing.

b. Operational Standards Procedures that are appropriately applied in the Business Management Field in the Production Unit of SMK Negeri 1 Panyabungan, both UP which serves as a learning resource and funding source, consists of 4 main stages, namely: Planning, Organizing, Implementation, and Supervision.

c. Output of Production Unit Management (UP) in SMK Negeri 1 Panyabungan are:

1) Practical planning of production units at SMK Negeri 1 Panyabungan Division of Business and Management is in the very good category with a percentage of $(93.00 \%)$. This score is obtained from the results of the average trial I $(90 \%)$ and Trial II (96\%).

2) Organization of production units in SMK Negeri 1 Panyabungan Division of Business and Management is in the very good category with a percentage of $(92.75 \%)$. This score is obtained from the results of the average trial I (87.5) with the Trial Results II (98\%). 
3) The implementation of production unit practices at SMK Negeri 1 Panyabungan in Business and Management is in the very good category with a percentage of $(94.50 \%)$. This score is obtained from the results of the average trial I $(95 \%)$ and Trial Results II (94\%).

4) Supervision of production unit practices at State SMK Negeri 1 Panyabungan Business and Management are included in the excellent category with a percentage of $(99 \%)$. This score is obtained from the results of the average Trial I $(100 \%)$ and Trial Results II (98\%).

\section{References}

[1] Pusat Bahasa, Kamus Besar Bahasa Indonesia. Jakarta: Departemen Pendidikan dan Kebudayaan RI, 2013.

[2] Martubi, "Models of Organizing Production Units in Yogyakarta Special Vocational Schools," J. Res. Inst., vol. 29, 1999.

[3] Malayu S.P. Hasibuan, Management: Basic, Understanding, and Problems. Jakarta: Bumi Aksara, 2007.

[4] Griffin and R. W, Management, 7th ed. Jakarta: Erlangga, 2004.

[5] H. . Mulyasa, Pengembangan dan Implementasi Kurikulum 2013. Bandung: Remaja Rosdakarya, 2013.

[6] R. Boyatzis, D. Goleman, and K. Rhee, "Clustering Competence in Emotional Intelligence: Insights from the Emotional Competence Inventory (ECI)," in Handbook of emotional intelligence, San Francisco: Jossey-Bass, 2000.

[7] W. R. Borg and M. D. Gall, Research Education: an Instruction. New York: Longman Tnc, 1983. 